\section{A review on fulminating gold (Knallgold)}

\section{Georg Steinhauser ${ }^{1,2 *}$, Jürgen Evers ${ }^{2}$, Stefanie Jakob², Thomas M. Klapötke², Gilbert Oehlinger ${ }^{2}$}

${ }^{1}$ Atominstitut der Österreichischen Universitäten, Vienna University of Technology, Stadionallee 2, 1020 Vienna, Austria

${ }^{2}$ Department of Chemistry and Biochemistry, LudwigMaximilians University of Munich, Butenandtstr. 5-13 (D), 81377 Munich, Germany

* Corresponding author.

E-mail address: georg.steinhauser@ati.ac.at

\section{Abstract}

Expensive and explosive! The reaction of ammonia and gold(III) compounds leads to explosive products known as "fulminating gold". Gold scientists should be aware of the potential hazards involved in the reaction of these starting materials. Herein, a historic and scientific review on this fascinating substance is presented. Fulminating gold has been known since medieval times, but cannot be fully characterized due to its polymeric and heterogeneous character. Magnetic measurements confirm previous EXAFS analyses that the gold atoms have a square planar coordination environment (AuN $\mathrm{N}_{4}$-moieties that are party connected and form a 3-dimensional network). The explosive properties and resulting safety instructions are discussed in detail as well.

Keywords: aurum fulminans, explosives, gold-nitrogen bond, safety, alchemists
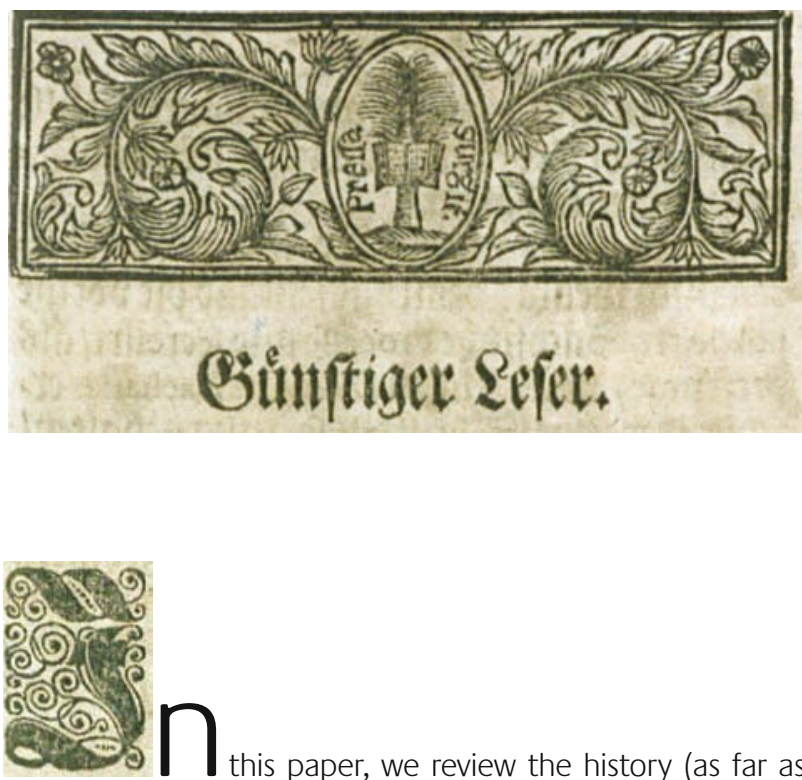
significant), the chemistry and hazards of fulminating gold. "Fulminating gold" generally terms the explosive reaction products of gold(III) compounds (such as halogenides, oxides and hydroxides) with ammonia. In this paper we focus on fulminating gold produced from gold(III) chloride or hydrogen tetrachloroaurate(III). This type of fulminating gold is also termed "Chloridknallgold" in literature. The expression "fulminating" might be confusing and should not be mistaken for the energetic fulminate anion $\left(\mathrm{CNO}^{-}\right)$.

\section{The History of the first high explosive}

The early work

Since fulminating gold is synthesized by using readily available chemicals - gold(III) chloride and ammonia - and leads to an unexpectedly explosive substance, it is no surprise that it has been known to alchemists since medieval times (alchemist symbol $\odot$ ). The German alchemist Sebald Schwaertzer first mentions fulminating gold (aurum fulminans) in literature in his Chrysopoeia Schwaertzeriana in 1585. A reprint of this monograph dates back to 1718 [1] (Translated: Manuscripts on the True Preparation of the Philosopher's Stone). It is still available in some German libraries (see Figure 1). 
Chryfopœia Schwærtzeriana.

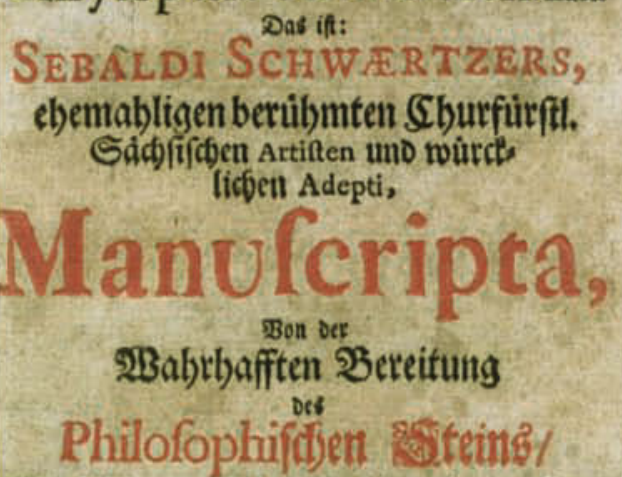
2Bie felbige vor oiefert mit feinet eigenen -5and entworffen/ uno bee Dem Ebursfureft. Sdidfifiden

Saufs in Originali verwabrlid aufbebalten worben/

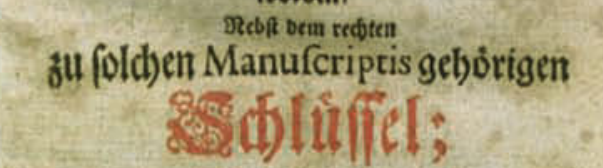

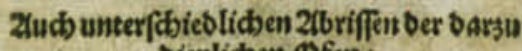
oienliden of fen!

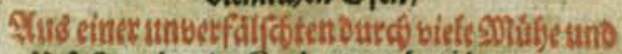

Infofter erlangten Copia nunmebro jeocrman vor

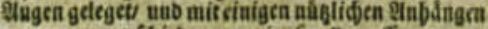
von verf́biebenen curieufen Proceflen vermebret.

HAMB URG, Dey Samut Stil/ in S. Johannis SPirde, 1718.

\%ి $(85)$ )

Antim. gehbret vor bie Subl(tr) man finbet audb bas bey sinen untcefliden 2ubgang am $O /$ foftet audb brey

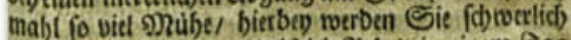
I lecen verlichren und ift Die 2lrbeit in cinem ₹ag

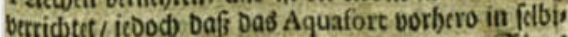

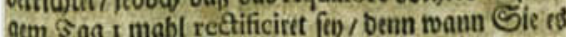
fóten/ vereinbabrt fid Dic Solution D mit Dem @ Das bo:b barbon foll gereiniget werben / binwieberum; vietwol wann ts nidst andert fenn fan / fo fdabet bas

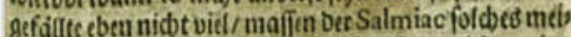

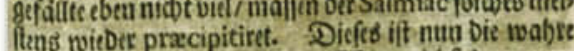
Philo(ophiftes Fetinigung; 23ann biefes nun ges trocentt / fo folviren Sile es mit reintem Aquafort unb Salmiac, biefen $\odot$ Ralce tvieberum in aller mafier wic

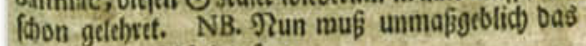
Aquafort rectificiet fenn.

₹un belieben Sic Dab Aquafort bis auf Dic Srocles

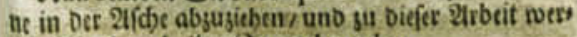
Den Sie cinen balben ₹ag gebrauden.

gBieberum belieben Sic frifdes $2 B$ affer aufģugiefs

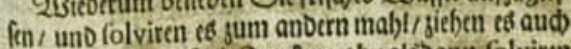
twieverum bis auf bie Srocene ab/alsbann folviren Giers bum britten mabl alfo. Sie muifenlaber adt seben / Dafi Sic es nid) gank fonbernnur balb absier hen / fa wiro Die Materia Delidet fevn/ bann nebmen

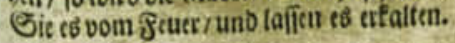

Dann procipitirn Sit bas $\odot$ mit Ol. Tartar., toclders folgender gefta!t gemad)t wird / Sie netjmen

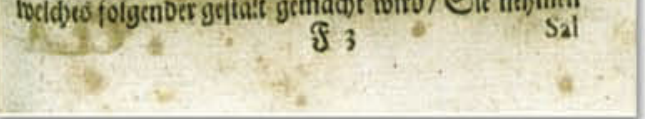

\section{* ( 84$)$ 8\%}

den; TRim Denn von ber Tinctur I Gran, lege fol

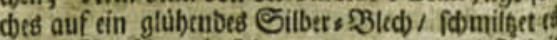
fonber SRaufiden/ baft bu getwonnen/ unb bie 2ilebers glúcflid) geenbet/ probire es benn auf $\not{q}$ ober $\delta$ \& videbitur cujus toni. Soli Deo Gloria.

4. Pbilofopbiced bas Aurum Fulminans 30 preparivent uno wie man felbiges sur bỏ hf ften Reis vigung bringet.

Sie belieben in tintr Phiole fu thun 8 goth $\odot$ su 16 goth Aquafort, Das feine bchorige Starcte batl

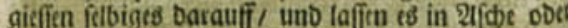
Sanb lautidt watm toerbenc alsoann nebraec Silt ofnaef(b) \& Eotb Salmiac, werfen Dente(ben aflmaly" lid binein/ und bas lo offte / bis Sie fecen / Dafi bas

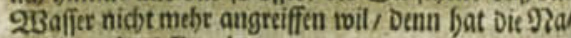
tur ibe redtes Pondus.

2Bann nun nidbte meffe folvirct/ gieffen Sie bie Solution, fo ferne ned) was tưcefftánbig $/ a b /$ uni procediren mit oem R efiduo gleidergeftalt/ bis allev Iolvirte ift.

Tun ncbmen Sie vor 3 ober 6 गुfenning Cypri(d)en Vitr, folviren foldes in Aqua comm, fileriren es / alfo/ Daßes tauter unb nicite trúbe (es) / biermil praxcipitiren Sic bas $\mathrm{O}$ / unb edulcoriren ben Rald

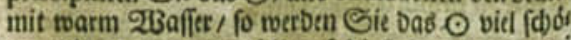
net/ als wenn es 3 mabl Durcb bie Spheram Saturni gangen wáks / vor Sid) finven/ (Dede 2lrbeit mit bent Antim.

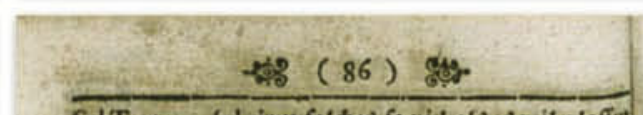

Sal Tartar., folviren folфts fo viel als es wil / laffeat es in einer 2abraud.Sdale evaporiten / legen Dent Das Sal im Setlee / fo fomilgete es per fe balbe/ bid fes ift oas fo genaite Lixivium Tartari, fiervon muff en Sie in frin (E)la voll beb ber Şanb baben / und biefes ednnen Sie wegen obiger 2lrbeit jugleid) mil verfertigen/ fo gewinnet man an ber 3etit viel.

2ुßnn Sit nun fiermit bas $\odot$ precipititen/ Inưf fen Sie bebutfam verfabren/ fonften fänget es an is fdlagen/ ober ldafit von bem 23 raufen tiber.

28 enn nun afles verbraufet unb bas $\odot$ precipitirtt ift / múffen Sic es wobl edulcoriten / bamit bas Sal barvon fomme / wann biefes gefdeben/ werbeal Sie cin fódnes \$y urpursfarbenes Aurum Fulminans vor Sid finbon.

Diefe Irbeit fan in 4 Eagen verriftet weroen / 6 ba $\beta$ man fu oer gangen 2urbeit nidbt über s ₹age ju bringet/ alsbann ift oie Philofophifde Praparation Des Auri Fulmin. geffotben. Sat dictum.

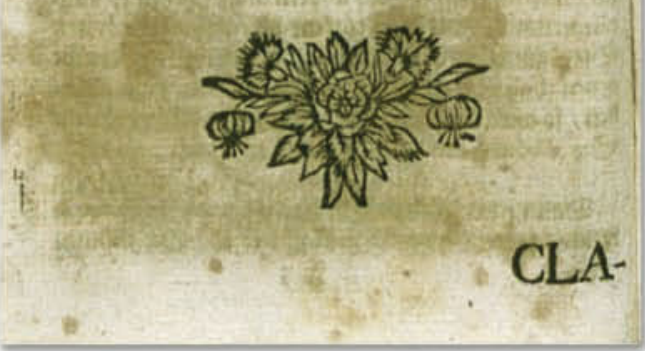


Unprofessionally translated, Schwaertzer writes:

\section{The philosophy of preparing the Aurum Fulminans and how to bring it to highest purity.}

You may wish to put 8 Lots [approx. 8x16 g!] of $\odot$ [gold] into a vial and to add 16 Lots of Aquafort [concentrated nitric acid], which has a considerable concentration / and gently warm it in [a bath of] ashes or sand / then take approximately 8 Lots of Salmiac [ammonium chloride] and slowly throw it into the beaker / do that / until you can see / that the water does not want to etch any further / then nature has its right Pondus.

Then take Cypric Vitriol [probably a mixture of $\mathrm{FeSO}_{4} \cdot 7$ $\mathrm{H}_{2} \mathrm{O}$ and $\mathrm{CuSO}_{4} \cdot 5 \mathrm{H}_{2} \mathrm{O}$ ] as much as you can get for 3 or 6 Pfennig, dissolve it in common water, filter it off / so that / it is clear and no longer turbid / herewith precipitate the $\odot$ / and edulcorate the lime [precipitate?] with warm water / so you will get the $\odot$ in much nicer form / than when it had been going through Spheram Saturni [lead spheres] [...] you will notice a significant loss of $\odot /$ it also takes threefold efforts [...] This is the true philosophic purification; When it is dried / dissolve it in Aquafort and Salmiac, this $\odot$ lime, as stated above.

You may wish to evaporate the Aquafort to dryness in ashes / and it will take you half a day to do this work.

Then pour fresh water onto it / and dissolve it another time / evaporate it to dryness / then dissolve it a third time. You must pay attention / that you do not evaporate it completely but only half of it / so the Materia will be oily / then take it from the fireplace / and let it cool down.

Then precipitate the $\odot$ with Ol. Tartar. [Oil of Tartar, concentrated potassium carbonate solution] [...] You have to be careful / when precipitating $\odot$ with that [Oil of Tartar] / otherwise it might start to strike [explode] / or it might cause heavy foaming and overflow.

As soon as everything is no longer effervescent and the - is precipitated / you need to edulcorate it / to let the salt escape / when this is finished / you will find a beautiful purple-colored Aurum Fulminans.

This work can be finished within 4 days / so that the complete work does not take longer than 5 days / then the philosophic preparation Auri Fulmin. is done.

Sat dictum.

It was Johann Kunckel von Löwenstern (1630-1703) who found the correct explanation for the formation of fulminating gold upon the addition of potassium carbonate to the gold(III) solution according to the original recipe: Since Schwaertzer used ammonium chloride for the production of aqua regia, the solution of hydrogen tetrachloroaurate(III) still contained a significant amount of ammonium ions, which readily set ammonia free when treated with a base like concentrated potassium carbonate solution.
However, fulminating gold is not only one of the first known "compounds" of gold, but it is the first high-explosive known to mankind, and even older than famous historic explosives like mercury(II) fulminate (Knallquecksilber) [2].

Interestingly, the alchemists of the 16th and 17th century believed that the shock wave of exploding fulminating gold aims downwards only [3]. This myth was "busted" by Thomas Willis [4] in a simple experiment. He heated a small amount of fulminating gold on a spoon and covered it with a coin. Upon explosion the coin flew to the rafters. Robert Hooke performed similar experiments and reformulated the ancient ideas of combustion on account of his observations.

Johann Rudolf Glauber (1604-1670) observed the purple fumes of exploding fulminating gold and used incredible amounts of this substance for the gold-plating of objects. Much later, two (less hazardous) technical applications are documented in patent literature: Photography on the basis of fulminating gold and silver compounds as the light-sensitive substances [5] and therapeutic uses of gold succinimide, which can be prepared from succinimide and gold compounds such as fulminating gold [6].

Probably almost every chemist of the 19th century once worked on fulminating gold, since its constitution was still unknown. In the course of these investigations, probably many explosions occurred. One severe incident of Jöns Jakob Berzelius in 1809 is documented [7]. He was injured by an explosion in the course of handling more than 10 grams (!) of fulminating gold. Some glass shards of the beaker perforated his left hand and injured his eyes. As a consequence of his injuries he had to stay for months in a darkened room until he could finally see again, although a certain opacity of his right eye remained for years. His wounded hand healed, too, leaving purple-colored scars.

\section{The work of Scheele, Lavoisier and Dumas}

Until the 19th century, many scientists still believed that fulminating gold can be produced by the reaction of milk of lime and gold(III) chloride or other chemical reactions. By analyzing fulminating gold, Carl Wilhelm Scheele found the evidence that ammonia is the only responsible reagent for its formation. He also proved that the gas that is generated upon its explosion, is (mostly) dinitrogen [8]. In a first attempt to define a chemical "formula" for fulminating gold, Antoine Lavoisier concluded from Scheele's work that it was an "oxide d'or ammoniacal" [9].

Jean Baptiste Dumas applied systematic chemical analysis to gain further insight into the fulminating gold [10]. He found that it consists not only of gold and nitrogen but also hydrogen and chlorine. He ground the substance with copper(II) oxide so that it could be heated and decomposed without explosion. From the decomposition products he calculated the elemental ratios. He concluded that fulminating gold was a salt with ammonium as the cation and a goldnitrogen compound (“azoture d'or") as the anion. 


\section{The work of Raschig}

Friedrich Raschig found that fulminating gold was not one homogeneous compound but a mixture of more than one compound [11]. Despite the fact, that fulminating gold contains a certain amount of oxygen, he suggested a mixture of $\mathrm{HN}=\mathrm{Au}-\mathrm{NH}_{2}$ and $\mathrm{HN}=\mathrm{Au}-\mathrm{Cl}$ and concluded that the goldnitrogen bonds of those amido and imido ligands are responsible for the explosive character. Although such goldnitrogen bonds often can be found in explosive gold compounds, e.g. the extremely explosive tetraazidoaurates(III) like $\mathrm{NH}_{4}\left[\mathrm{Au}\left(\mathrm{N}_{3}\right)_{4}\right]$ [12], numerous examples of non-explosive compounds containing $\mathrm{Au}-\mathrm{N}-\mathrm{bonds}$ are known, e.g. the amide $\quad\left[\left(\mathrm{CH}_{3}\right)_{2} \mathrm{AuNH}_{2}\right]_{4}$ and $\left[\left(\mathrm{CH}_{3}\right)_{2} \mathrm{AuN}\left(\mathrm{CH}_{3}\right)_{2}\right]_{2} \quad$ [13], $\left[\mathrm{Au}\left(\mathrm{NH}_{3}\right)_{4}\right]\left(\mathrm{NO}_{3}\right)_{3}$ [14], [AuCl $\left.\mathrm{NH}_{3}\right]$ [15], $\left[\mathrm{AuBr}{ }_{2}\left(\mathrm{NH}_{3}\right)_{2}\right]^{+}$[16]. Raschig's assumption was therefore too general but a good basis for further studies.

However, some hundred years later, Hans-Norbert Adams [17] found that $\left[\mathrm{Au}\left(\mathrm{NH}_{3}\right)_{4}\right]\left(\mathrm{NO}_{3}\right)_{3}$ leads to the formation of a very explosive compound, when treated with sodium amide in liquid ammonia under water-free conditions. In a Guinier powder diffractogram, he could identify ammonium nitrate as a by-product of this reaction [18]. Adams concludes that this indicates the primary formation of amido ligands. From this observation it is likely that some gold(III) amides are explosives, too. However, fulminating gold definitely does not consist of isolated amide/imide compounds according to Raschig's suggestion.

\section{The work of Weitz}

Ernst Weitz [19] investigated the constitution of fulminating gold in one of the most comprehensive studies ever performed on this topic. He used all analytical methods that were state of the art at that time and gained more scientific information about this extraordinary explosive substance. Some of his results were of fundamental character for all further studies. Nevertheless, he finally erroneously concluded that fulminating gold was a mixture (ratio of $\mathrm{Au}: \mathrm{N}=1: 1.5)$ of "diamido-imido-aurichloride" $\left(\mathrm{Cl}\left(\mathrm{NH}_{2}\right) \mathrm{Au}-\mathrm{NH}-\mathrm{Au}\left(\mathrm{NH}_{2}\right) \mathrm{Cl}\right)$ and $\mathrm{Au}_{2} \mathrm{O}_{3} \cdot 3 \mathrm{NH}_{3}$ (or $2 \mathrm{Au}(\mathrm{OH})_{3} \cdot 3 \mathrm{NH}_{3}$, respectively). He ignored the very poor solubility of fulminating gold in most solvents; from a chemist's point of view, one would expect a certain solubility at least for the isolated $\mathrm{Cl}\left(\mathrm{NH}_{2}\right) \mathrm{Au}-\mathrm{NH}-\mathrm{Au}\left(\mathrm{NH}_{2}\right) \mathrm{Cl}$ molecule. However, he was correct that fulminating gold has an extremely high tendency of formation in the aqueous system gold(III) - ammonia - chlorine.

\section{The latest works}

Several decades later, Professor Joachim Strähle (University of Tübingen, Germany) and his co-workers Hans-Norbert Adams, Ulrich Gräßle and Joannis Psilitelis (in collaboration with Prof. Helmut Bertagnolli, Stuttgart), made - to the authors' knowledge - the last major attempts to solve the problem of the constitution of fulminating gold [18, 20, 21]. Their results will be discussed extensively in the following sections.

\section{The Chemistry of fulminating gold}

\section{General aspects}

Some reactions in the system gold - ammonia are summarized in Scheme 1 (below).

Tetraamminegold(III) nitrate, $\left[\mathrm{Au}\left(\mathrm{NH}_{3}\right)_{4}\right]\left(\mathrm{NO}_{3}\right)_{3}$, is the only exception, where, due to the excess of $\mathrm{NH}_{4}{ }^{+}$and $\mathrm{NO}_{3}{ }^{-}$ions, a reaction of ammonia and hydrogen tetrachloroaurate(III)

Scheme 1

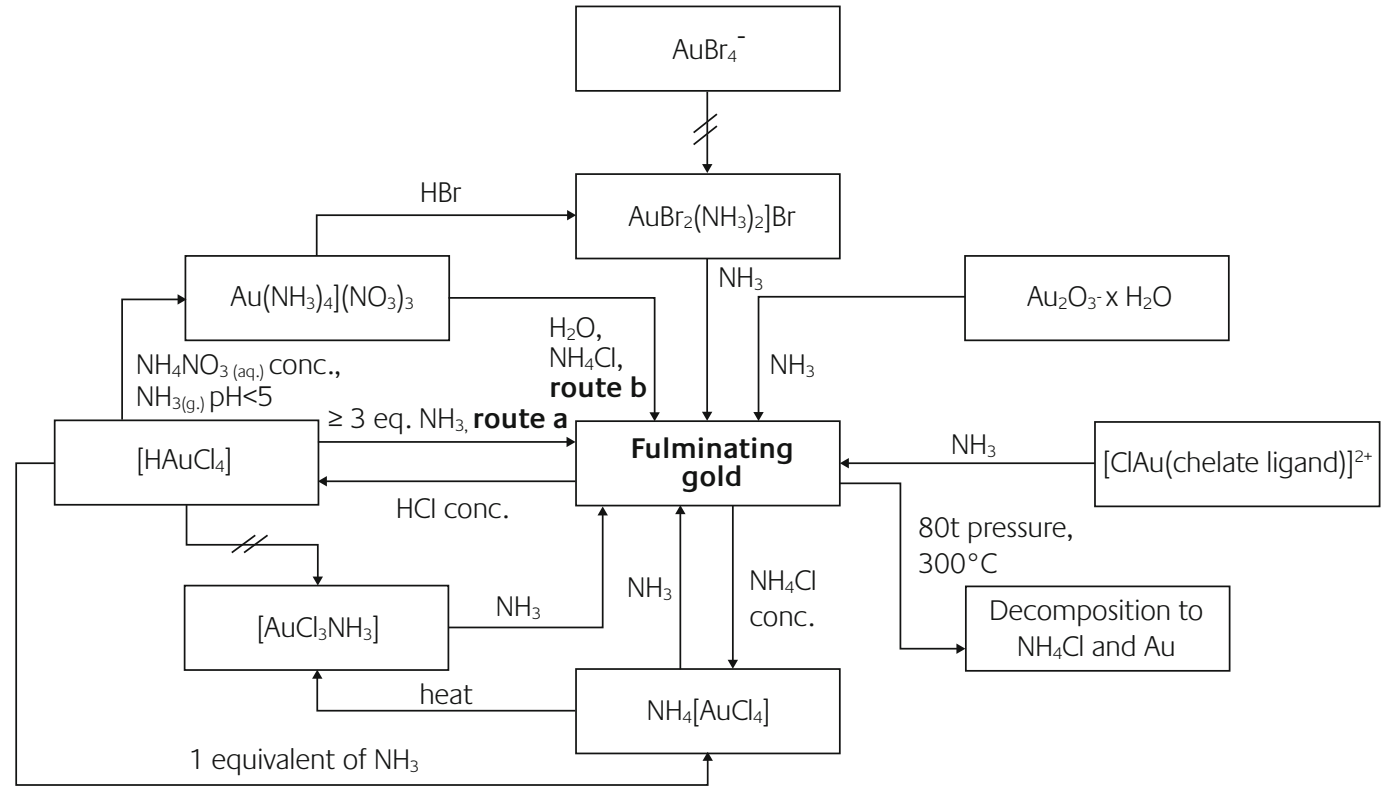

Overview of some reactions in the system gold - ammonia, partly after [18, 19] 


\section{Figure 2}
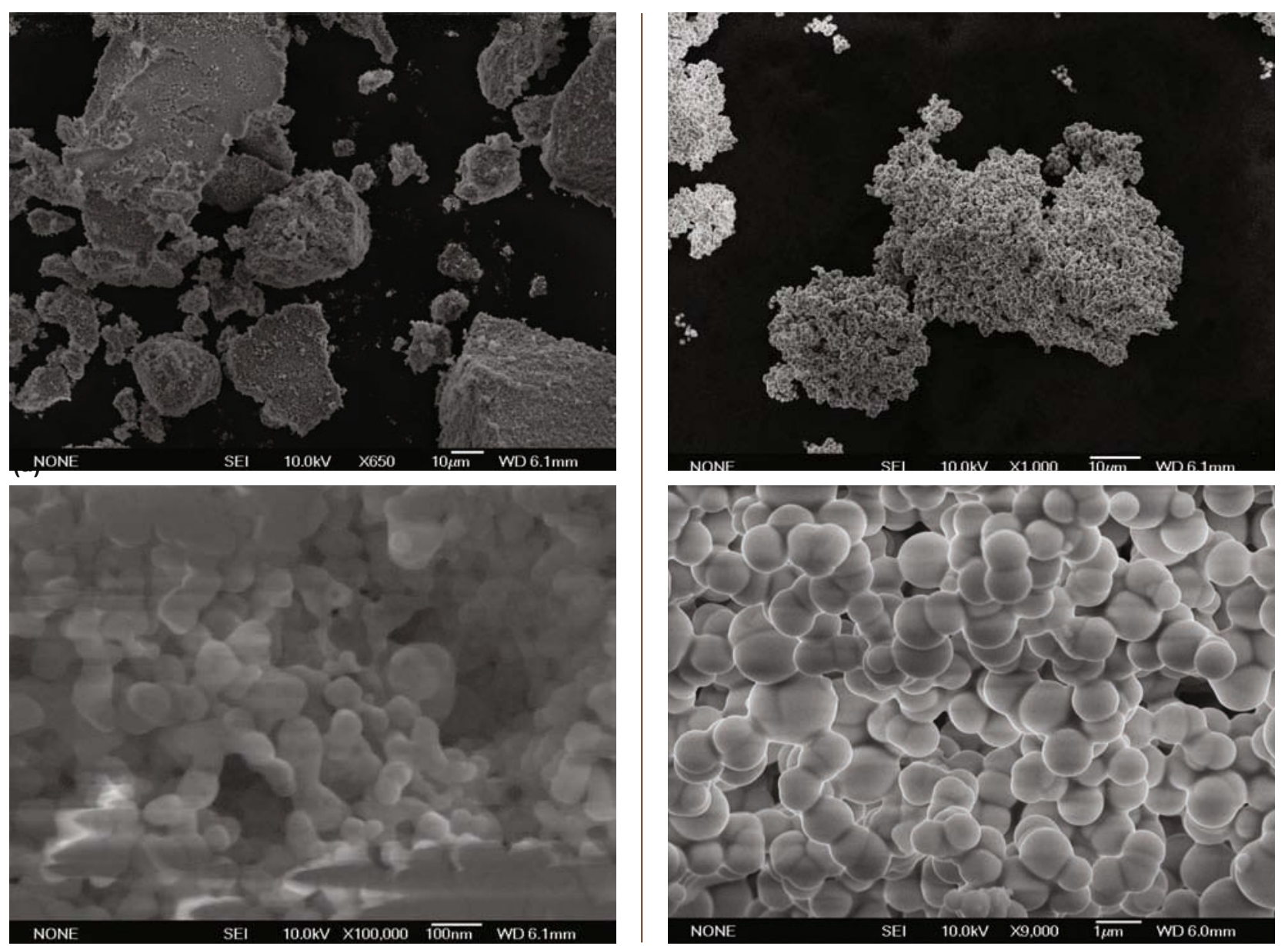

Fulminating gold produced via route a

EDX analysis (mass -\%)

Au 86, N 5, Ci 9, O not detected

Fulminating gold produced via route $\boldsymbol{b}$

EDX analysis (mass -\%)

$\mathrm{Au}$ 73, N 12, Ci 12, $\mathrm{O} 3$

SEM pictures of fulminating gold

does not yield fulminating gold [14]. The tetraamminegold(III) ion has been intense object of investigation with respect to stability and acid dissociation [22], vibrational spectroscopical properties [23] and its comproportionation with gold to the corresponding diamminegold(I) complex [24]. Weitz observed that the hydrolysis of $\left[\mathrm{Au}\left(\mathrm{NH}_{3}\right)_{4}\right]\left(\mathrm{NO}_{3}\right)_{3}$ with the mild Lewis base $\mathrm{Cl}^{-}$(route $\mathbf{b}$ ) leads to a seemingly homogeneous species of fulminating gold. He therefore - erroneously concluded that this product was a "quite pure" $\mathrm{Cl}\left(\mathrm{NH}_{2}\right) \mathrm{Au}-$ $\mathrm{NH}-\mathrm{Au}\left(\mathrm{NH}_{2}\right) \mathrm{Cl}$. Indeed, route $\mathbf{b}$ is the method of choice if a homogeneous (with respect to color, grain size and macroscopic morphology) and hardly explosive product is desired. The morphologic differences in fulminating gold, whether produced via route $\mathbf{a}$ or $\mathbf{b}$ are shown in the electron microscope pictures in Figure 2. Energy Dispersive X-Ray (EDX) analytical data should be regarded rather as qualitative than as quantitative information.

Route b fulminating gold appears as partly welded globules with a size of approximately $1 \mu \mathrm{m}$ in diameter, whereas the same substance synthesized via route a consists of much smaller particles (50 nm) of different shapes and morphologies. In both pictures, crystalline structures are completely missing. We also applied powder X-ray powder diffraction to several batches of fulminating gold and found that it was amorphous only (only one broad glass-peak appeared in the diffractograms).

\section{Crystallization of fulminating gold}

The most reliable way of characterizing a compound is crystal structure analysis by X-ray diffraction. Many methods are known for the growing of single crystals or crystalline powder, partly after [18]:

1. Crystal growth from the gas phase
a) by chemical reactions
b) by transport reactions
c) by sublimation

2. Crystal growth in a molten materials

3. Crystal growth in solid phase
a) by recrystallization
b) by polyphase-diffusion

4. Crystal growth in solutions

a) by recrystallization 
b) by diffusion and chemical reactions

5. Crystal growth under hydrothermal conditions

6. Crystallization of amorphous substances under high pressure and/or high temperatures.

Adams concluded that due to its physical and chemical properties, crystallization of fulminating gold cannot be achieved by methods 1), 2), 3) and 4a). In general, we agree with this hypothesis. Fulminating gold decomposes at approximately $210^{\circ} \mathrm{C}$ (sometimes with explosion) without melting. Sublimation leads to decomposition or explosion of fulminating gold. Ammonium chloride could be identified by X-ray diffraction as one subliming decomposition product. One tiny greenish-yellow crystal could be isolated from a Mark-tube, in which we tried to temper and/or sublime fulminating gold $\left(1\right.$ week at $200^{\circ} \mathrm{C}$ ). With a size of only a few microns, it was too small to determine the crystal structure. However, we believe that the crystal contains gold and light atoms only, but no chlorine. The crystallographical cell could be vaguely determined (see Table 1).

Adams stated that fulminating gold is insoluble and cannot be crystallized from solutions. However, in this study, several solvents were applied to investigate the solubility of fulminating gold: carbon tetrachloride, nitrobenzene, hexamethylphosphoric triamide, acetonitrile, dimethylsulfoxide and dimethylformamide. To our surprise, we found that, after almost two months, small amounts of fulminating gold (route a) dissolved in acetonitrile and dimethylformamide. This fact could be observed by the yellowish-green color of the solution. The other solvents remained colorless. Recrystallization from the solution by slow evaporation or by influencing the solvent's polarity in an ether chamber, however, failed as well. Evaporation of the solvent forms a small amount of amorphous material again, which readily dissolves in the same solvent again.

A couple of experiments aiming at the crystallization of fulminating gold in gels have been performed previously and in this study. In general, the slow diffusion velocity in gels drastically decreases the formation of seed crystals, and allows the crystallization of large crystals of compounds that usually form fine precipitates like silver chloride or calcium carbonate - just like fulminating gold. Adams attempted the crystallization of fulminating gold in sodium silicate-derived silica gels under different conditions, by varying the gel's density, the concentrations of the starting materials, the gel's $\mathrm{pH}$ value or by application of homogeneous and heterogeneous formation of seed crystals (AuOCl crystals), by different geometries of the experimental apparatus or by application of liquid ammonia under high pressure. He always obtained amorphous precipitates or metallic gold (at high pH values). Our experiments in gels prepared from aqueous tetramethoxysilane suspensions failed as well and only yielded amorphous brownish-yellow precipitates.

Like Adams, we found that crystallization of fulminating gold by applying gaseous ammonia to solutions of hydrogen tetrachloroaurate(III) fails.

In this study, crystallization at high pressures and elevated

\section{Table 1}

Crystallographical cell of a sublimation/tempering product of fulminating gold: (single crystal diffractometry, 233 reflections used for cell determination)

\begin{tabular}{|c|c|c|c|c|c|c|c|c|}
\hline $\mathrm{a} / \AA$ & $\mathrm{b} / \AA$ & $c / \AA$ & $\alpha /^{\circ}$ & $\beta /^{\circ}$ & $\gamma /{ }^{\circ}$ & $V / \AA^{3}$ & Crystal system & Lattice \\
\hline 7.641 & 7.853 & 7.855 & 75.63 & 81.76 & 75.03 & 439.5 & triclinic & $P$-lattice \\
\hline
\end{tabular}

\section{Figure 3}
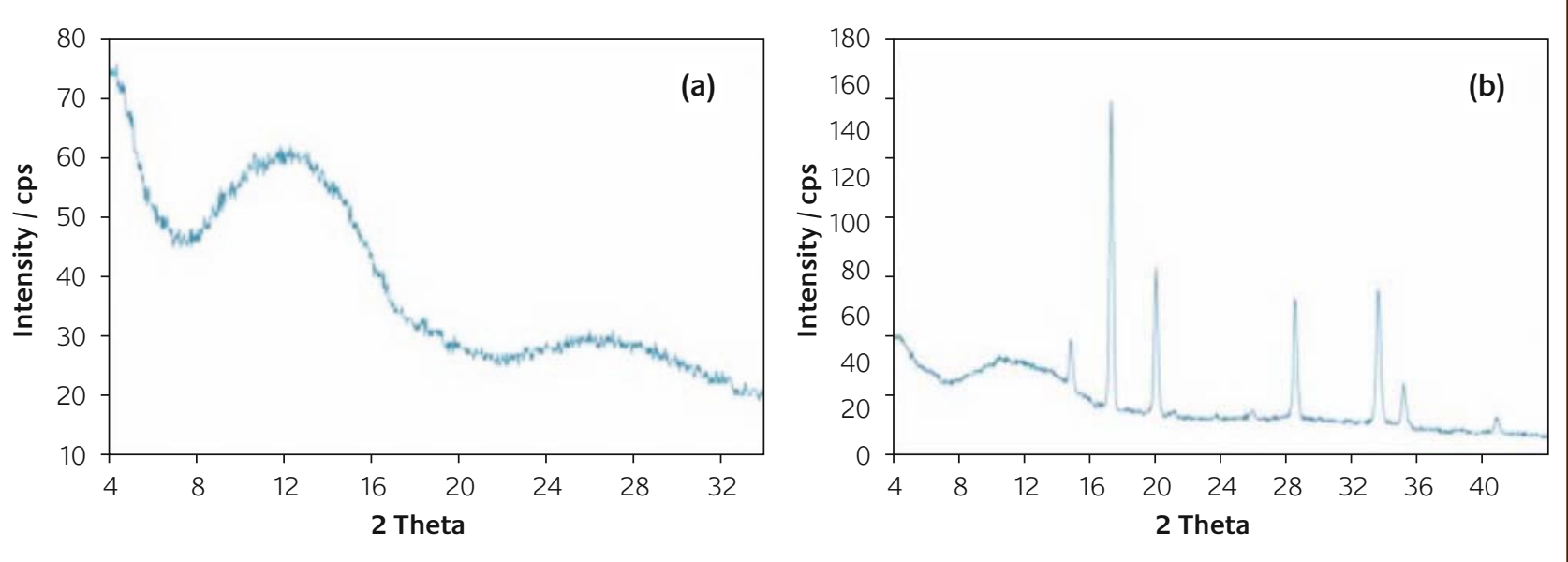

Two diffractograms of fulminating gold pressed at 80 tons (40 kbar) and $190^{\circ} \mathrm{C}$ (a) and $230^{\circ} \mathrm{C}$ (b), respectively. In (a), only the broad glass peak can be observed, whereas in (b) the same glass peak as well as the peaks of the decomposition products (Au and $\left.\mathrm{NH}_{4} \mathrm{Cl}\right)$ are shown 
temperatures was attempted. For this purpose, amounts of approx. $35 \mathrm{mg}$ of fulminating gold were filled in boron nitride crucibles and pressed in a belt-apparatus at 80 tons [25]. Three experiments with different temperatures were conducted; 190,230 and $300^{\circ} \mathrm{C}$. After one hour, the gold compound was filled in a Mark-tube and measured with the Guinier X-ray powder diffractometer. In case of $190^{\circ} \mathrm{C}$, the substance was still amorphous. At higher temperatures, characteristic peaks of ammonium chloride and crystalline metallic gold appeared in the diffractogram (see Fig. 3). Therefore, fulminating gold decomposes even at high pressure and elevated temperature without prior crystallization. This method, by the way, could be an effective method for the production of highly X-ray diffracting crystalline gold powder.

From all these facts discussed above, it can be concluded that fulminating gold is an amorphous mixture of probably polymeric compounds - a condensation product of $\left[\mathrm{Au}\left(\mathrm{NH}_{3}\right)_{4}\right]^{3+}$ on the way to $\mathrm{Au} \equiv \mathrm{N}$. The gold atoms are linked via $\mu-\mathrm{NH}_{2}$ and $\mu_{3}-\mathrm{NH}$ bridges, as indicated by vibrational spectroscopy by [18]. Adams suggests that fulminating gold is the product of hydrolysis of ${ }_{\infty}^{3}\left[\mathrm{Au}_{2}\left(\mu-\mathrm{NH}_{2}\right)(\mu 3-\mathrm{NH})_{2}\right] \mathrm{Cl}$.

\section{EXAFS analyses}

In his PhD thesis, Joannis Psilitelis applied EXAFS (Extended XRay Absorption Fine Structure) measurements to gain insight to the structural constitution of fulminating gold [21]. This method can be used within various types of substances, even in amorphous and heterogeneous materials and liquids. He found that even in fulminating gold precipitated with only a slight excess of ammonia, a gold atom is no longer coordinated by chlorine atoms but exclusively by nitrogen atoms in its first coordination sphere (see Fig. 4).

This is in exact agreement with the coordination mode of the square planar tetraamminegold(III) cation (Au-N bond length 202 pm) [14]. In a second coordination sphere, there are either four gold atoms or only one (in a distance of $350 \mathrm{pm}$ to the centered gold atom). In one possible interpretation, the gold atoms of both spheres can be connected by an $\mathrm{Au}-\mathrm{N}-\mathrm{Au}$ bridge (angle $120^{\circ}$ ) or, alternatively,

\section{Figure 4}

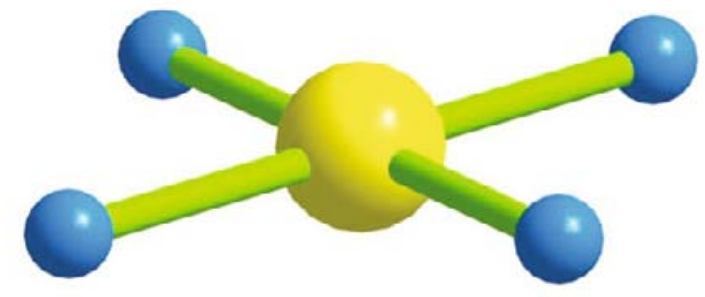

The fundamental, square planar AuN $N_{4}$-moiety of fulminating gold. The atomic distances are $202 \mathrm{pm}$ for all $\mathrm{Au}-\mathrm{N}$ bonds, and the angles are $90^{\circ}$ and $180^{\circ}$, respectively fulminating gold is built of planar layers of $\mathrm{AuN}_{4}$-moieties. The existence of $\mathrm{Au}-\mathrm{N}$ bonds has been evidenced by vibrational spectroscopy as well.

\section{Magnetic measurements}

Magnetic susceptibilities were determined with a SQUID magnetometer (MPMS-XL5, Quantum Design Inc.) between 4 and $400 \mathrm{~K}$ with magnetic flux densities up to 5 Tesla. Samples of about $15 \mathrm{mg}$ of fulminating gold (type b) were loaded in gelatin capsules and fixed in a straw as the sample holder. The data were corrected for the sample holder and the core diamagnetism. We measured the magnetic susceptibilities in magnetic flux densities of 0.8 Tesla, 1 Tesla, 2 Tesla and 5 Tesla. The sample is diamagnetic, but shows different susceptibilities at $300 \mathrm{~K}$ :

$$
\begin{aligned}
& \chi g(0.8 \mathrm{~T})=-3.09 \times 10^{-7} \mathrm{~g}^{-1} \mathrm{~cm}^{3} \\
& \chi g(1 \mathrm{~T})=-3.13 \times 10^{-7} \mathrm{~g}^{-1} \mathrm{~cm}^{3} \\
& \chi g(2 \mathrm{~T})=-3.54 \times 10^{-7} \mathrm{~g}^{-1} \mathrm{~cm}^{3} \\
& \chi g(5 \mathrm{~T})=-3.35 \times 10^{-7} \mathrm{~g}^{-1} \mathrm{~cm}^{3}
\end{aligned}
$$

Figure 5 shows the temperature dependency of the magnetic susceptibility in a magnetic flux density of 2 Tesla. The diamagnetic character of fulminating gold offers structural information. For ions with a $\mathrm{d}^{8}$ electron configuration, diamagnetism occurs only in a strictly square planar coordination environment $[26,27]$. A deviation from this geometry results in paramagnetism for $\mathrm{d}^{8}$ compounds. From this fact, we can confirm the square planarity of the $\mathrm{AuN}_{4}$ moiety which has also been found in previous EXAFS analyses (see above and Figure 4).

\section{Figure 5}

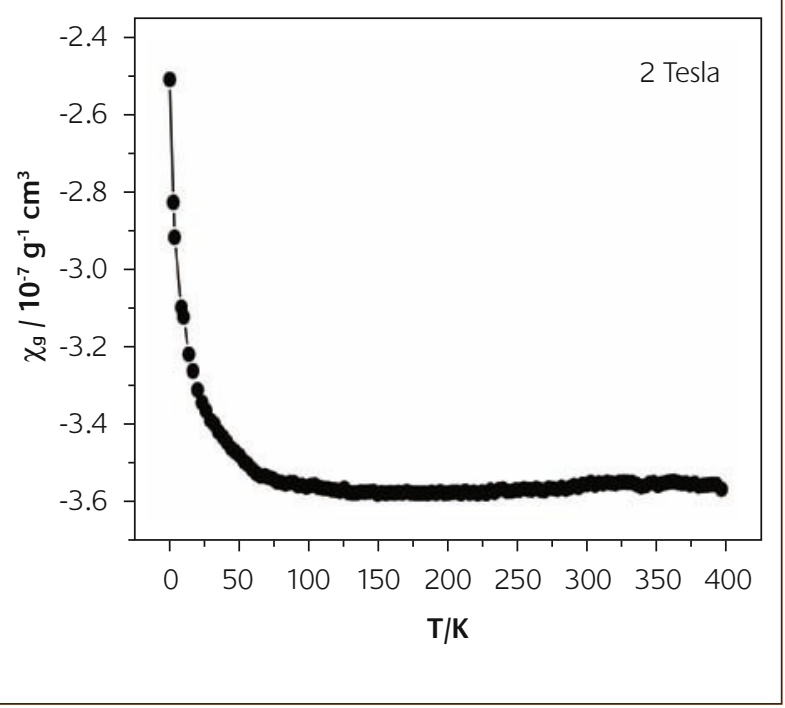

Temperature dependency of the magnetic susceptibility of fulminating gold (magnetic flux density of 2 Tesla) 
A selection of elemental analyses (expressed as atomic ratios), after [18]

\begin{tabular}{|c|c|c|c|c|c|c|c|c|c|}
\hline \multirow[t]{2}{*}{$\begin{array}{l}\text { Mol } \mathrm{NH}_{3} \\
\text { per Au }\end{array}$} & \multicolumn{4}{|c|}{$\begin{array}{l}\text { Atomic ratio in fulminating } \\
\text { gold, data taken from [18] }\end{array}$} & \multicolumn{3}{|c|}{$\begin{array}{l}\text { Atomic ratio in fulminating } \\
\text { gold, data taken from [19] }\end{array}$} & \multirow[t]{2}{*}{$\begin{array}{l}\mathrm{pH} \text { of } \\
\text { solution }\end{array}$} & \multirow[t]{2}{*}{$\begin{array}{l}\text { Explosive } \\
\text { properties }\end{array}$} \\
\hline & $\mathrm{Au}$ & $\mathrm{N}$ & $\mathrm{Cl}$ & $\mathrm{O}^{1)}$ & $\mathrm{Au}$ & $N$ & $\mathrm{Cl}$ & & \\
\hline 3 & 1.0 & 0.95 & 1.36 & 0.33 & & & & slightly acidic & $\begin{array}{l}\text { Deflagration } \\
\text { upon heating }\end{array}$ \\
\hline 4 & 1.0 & 1.11 & 1.02 & 0.43 & 1.0 & 1.16 & 1.12 & neutral & \\
\hline 4 & & & & & 1.0 & 0.99 & 1.07 & & \\
\hline 5 & 1.0 & 1.33 & 0.55 & 0.54 & 1.0 & 1.49 & 0.64 & slightly basic & \\
\hline 6 & 1.0 & 1.35 & 0.44 & 0.84 & 1.0 & 1.47 & 0.59 & & \\
\hline 8 & 1.0 & 1.36 & 0.32 & 0.87 & 1.0 & 1.51 & 0.52 & basic & \\
\hline $8^{3)}$ & 1.0 & 1.38 & 0.28 & 1.07 & 1.0 & 1.49 & 0.47 & & $\begin{array}{l}\text { Explosion upon } \\
\text { impact }\end{array}$ \\
\hline
\end{tabular}

1) The residue to $100 \%$ is assumed to be $O$ (neglecting the content of hydrogen).

2) Analysis of the solutions and conclusion to the composition of the precipitate.

3) After washing several times with water.

\section{Electrical experiments}

In our attempts to measure the electrical resistivity of fulminating gold, it soon became evident, that strongly reproducible results are not easily obtained by simple fourprobe-techniques at ambient pressure. However, fulminating gold is a substance with a very high electrical resistivity. This approves that ammonia does not reduce the $\mathrm{Au}^{3+}$ ions to metallic gold. Nevertheless, additional attempts were made to measure the electrical resistivity in the belt apparatus with only two contacts at variable pressures up to $40 \mathrm{kbar}$ (using route $\mathbf{b}$ fulminating gold). Here some indications were found that the electrical resistivity of fulminating gold decreases with increasing pressure. In order to establish this effect quantitatively, it is intended to measure the resistance in a diamond anvil cell up to several hundred kilobars at ambient temperature.

\section{Elemental analyses}

In the reaction of gold(III) compounds and ammonia, fulminating gold is formed only with an ammonia excess of at least a factor of three in relation to $\mathrm{Au}^{3+}$. An equimolar addition of diluted ammonia solution leads to the formation of $\mathrm{NH}_{4}\left[\mathrm{AuCl}_{4}\right]$ [15]. However, the fulminating gold species show different elementary analyses as a function of the precipitation conditions, primarily the amount of ammonia added. These hardly predictable differences have been observed already by Weitz and Adams (see Table 2).

Believing that Adam's results are the more reliable due to the use of modern elemental analytical facilities, extreme values of 1.4 atoms nitrogen and 0.3 atoms chlorine per atom gold are obvious from Table 2 .

It is obvious that with increasing amounts of ammonia in the course of precipitation (or washing), the content of chlorine in the product decreases, so does washing with pure water. Obviously, $\mathrm{Cl}^{-}$is then substituted by $\mathrm{OH}^{-}$or $\mathrm{O}^{2-}$. The results of an elemental analysis vary therefore from batch to batch. Reproducible syntheses of fulminating gold with identical elemental analytical values are hardly possible. In our investigations, we found that fulminating gold produced via route $\mathbf{a}$ is not even homogeneous within one batch. Two samples (a light one with light brownish-yellow color and a dark brown-colored one) of one precipitation batch were submitted to elemental analysis $(\mathrm{H}$ and $\mathrm{N}$ determined by a

\section{Table 3}

Some elemental analyses of fulminating gold (mass-\%). Bold figures are from the same precipitation batch (n.d. = not determined)

\begin{tabular}{|c|c|c|c|c|c|}
\hline $\begin{array}{l}\text { Sample } \\
\text { code }\end{array}$ & $\begin{array}{l}\text { Route of producti } \\
\text { (see Scheme 1) }\end{array}$ & $\begin{array}{l}\text { ion } \\
\mathrm{Au}\end{array}$ & $\mathbf{N}$ & $\mathrm{H}$ & $\mathrm{Cl}$ \\
\hline 29 & $\mathrm{a}\left(\mathrm{Au}^{3+}: \mathrm{NH}_{3} \approx 1: 3\right)$ & 79.5 & 6.33 & 1.27 & 10.60 \\
\hline 30 & $\mathrm{a}$ & 78.8 & n.d. & n.d. & n.d. \\
\hline 45 & $\mathrm{a}$ & 81.0 & n.d. & n.d. & n.d. \\
\hline $\begin{array}{l}64 a \\
\text { (dark brown }\end{array}$ & $\begin{array}{l}\text { a } \\
\text { raction) }\end{array}$ & 84.3 & 5.88 & 1.14 & 15.82 \\
\hline $\begin{array}{l}\text { 64b } \\
\text { (light brown }\end{array}$ & $\begin{array}{l}\text { a } \\
\text { raction) }\end{array}$ & 90.5 & 7.22 & 1.39 & 9.12 \\
\hline 65 & $b$ & 87.8 & 9.81 & 1.75 & 9.19 \\
\hline 77 & $b$ & n.d. & 10.09 & 1.71 & 11.30 \\
\hline
\end{tabular}

Fulminating gold produced via route $b$ is characterized by higher homogeneity from the first sight than when synthesized via route a. Interestingly, despite its much higher nitrogen content, route $b$ fulminating gold is less explosive than the route a product 
vario EL elemental analyzer, Cl by a Metrohm Titroprocessor 686 analyzer) and showed two very different compositions (see Table 3, samples 64a and b). The gold content (determined by ICP-AES) varies to a large extent as well. In several samples, it is so high that the sum of the constituents would theoretically be far beyond $100 \%$. This is also a good indication for inhomogeneties within the batch.

\section{Derivatives of fulminating gold}

Several organic amines have been applied instead of ammonia to gain insight into the chemistry of fulminating gold by reducing the possibilities of the formation of bridges via the nitrogen atoms [18]. Indeed, the product of the reaction of hydrogen tetrachloroaurate(III) and monomethylamine is a significantly less explosive light brownish amorphous precipitate. It is assumed that the methyl group blocks one possible link on the nitrogen atoms for the formation of a three-dimensional network. The explosive character of fulminating gold increases with the degree of cross-linking. When dimethylamine is used, a second hydrogen of $\mathrm{NH}_{3}$ is substituted by a methyl group. Thus, the formation of a fulminating gold-type polymer is impossible and the reaction with $\mathrm{H}\left[\mathrm{AuCl}_{4}\right]$ yields a crystalline product - the adduct compound $\mathrm{AuCl}_{3} \cdot \mathrm{NH}\left(\mathrm{CH}_{3}\right)_{2}$. The use of primary amines large alkyl groups, e.g. mono-t-butyl-amine, hinders the formation of a three-dimensional polymer as well. The product of the corresponding reaction with $\left.\mathrm{H}_{\mathrm{AuCl}}\right]$ is the crystalline adduct compound of the above type [18].

Adams investigated the reactions of bisethylenediamine gold(III) chloride as a model substance for fulminating gold [18]. In analogy to $\left[\mathrm{Au}\left(\mathrm{NH}_{3}\right)_{4}\right]\left(\mathrm{NO}_{3}\right)_{3},\left[\mathrm{Au}(\mathrm{en})_{2}\right] \mathrm{Cl}_{3}$ reacts with bases and forms $\left[\mathrm{Au}(\mathrm{en})\left(\mathrm{en}_{2}-\mathrm{H}\right)\right] \mathrm{Cl}_{2}$. It can be deprotonated further in a reaction with sodium amide, yielding $\left[\mathrm{Au}\left(\mathrm{en}_{2}-2 \mathrm{H}\right)\right] \mathrm{Cl}$. Both compounds are suitable analogs to fulminating gold and $\left[\mathrm{Au}(\mathrm{en})\left(\mathrm{en}_{2}-\mathrm{H}\right)\right] \mathrm{Cl}_{2}$ is even slightly explosive upon heating.

The above mentioned gold-nitrogen heterocycles $\left[\left(\mathrm{CH}_{3}\right)_{2} \mathrm{AuNH}_{2}\right]_{4},\left[\left(\mathrm{CH}_{3}\right)_{2} \mathrm{AuN}\left(\mathrm{CH}_{3}\right)_{2}\right]_{2}[13],\left[\left(\mathrm{CH}_{3}\right)_{2} \mathrm{AuNH}_{2}\right]_{3}[28]$ and $\left[\left(\mathrm{CH}_{3}\right)_{2} \mathrm{AuNHCH}_{3}\right]_{2}[29]$ are mostly light sensitive but not explosive derivatives of fulminating gold. Several pyridine derivatives should be mentioned at this point as well: $\mathrm{Hpy}\left[\mathrm{AuCl}_{4}\right], \mathrm{AuCl}_{3} \cdot \mathrm{py},\left[\mathrm{AuCl}_{2}(\mathrm{py})_{2}\right] \mathrm{Cl}_{2} \mathrm{H}_{2} \mathrm{O}$ and $\left[\mathrm{AuCl}_{2}(\mathrm{py})_{2}\right]\left[\mathrm{AuCl}_{2}\right]$ [30]. In another study, AuCl-py, AuBr-py, Aulpy have been investigated [31, 32]. These compounds are light sensitive substances. The iodine compound is thermally instable and quickly decomposes above $0^{\circ} \mathrm{C}$. Both compounds show interesting luminescence properties.

We investigated the reaction of anhydrous $\mathrm{AuCl}_{3}$ and $\mathrm{N}\left(\mathrm{Si}\left(\mathrm{CH}_{3}\right)_{3}\right)_{3}$ in absolute diethyl ether. Tris(trimethylsilyl)amine reacts much slower than ammonia or conventional organic amines. After several hours of stirring at room temperature, a small amount of a brown precipitate formed. Investigation by means of X-ray powder diffraction evidenced a partial reduction crystalline gold only. The precipitate itself was amorphous and not explosive (in the flame of a Bunsen burner).

\section{Experimental}

In this study we synthesized fulminating gold via route $\mathbf{a}$ and $\mathbf{b}$.

Route a-fulminating gold was synthesized primarily by the reaction of gaseous ammonia with aqueous solutions of hydrogen tetrachloroaurate(III) $\left(\mathrm{H} \mathrm{AuCl}_{4} \cdot 3 \mathrm{H}_{2} \mathrm{O}(99.9 \%\right.$, Sigma Aldrich). This strategy provided a continuous reaction of $\mathrm{Au}^{3+}$ and $\mathrm{NH}_{3}$ avoiding a local over concentration of ammonia, which would yield a less homogeneous and more explosive and sensitive product. Generally, a beaker with aqueous hydrogen tetrachloroaurate(III) solution ([ $\left.\mathrm{Au}^{3+}\right]=10 \mathrm{mg} / \mathrm{ml}$ ) and a beaker with aqueous ammonia (25\%) were positioned in an empty desiccator. Precipitation of fulminating gold started within few minutes and generally completed after less than 30 minutes. At this point, the residual aqueous solution was colorless or slightly yellow at most. The precipitate was removed from the solution by filtration or centrifugation and washed with a minimum amount of water. Drying was performed in a desiccator over phosphorus pentoxide. Only for the determination of the explosive properties (drop hammer and friction sensitivity), route afulminating gold was precipitated in a direct reaction of aqueous $\mathrm{H}\left[\mathrm{AuCl}_{4}\right]$ and aqueous $\mathrm{NH}_{3}$ in the molar ratio of $1: 3$ and $1: 8$, respectively. The color of route a-fulminating gold varies from light to dark brown, sometimes slightly yellowish, greenish or reddish, sometimes slightly purple (see Fig. 6).

Route b-fulminating gold was synthesized in a two step synthesis, according to [19]. Firstly, the hydrogen tetrachloroaurate(III) solution $\left(\left[\mathrm{Au}^{3+}\right]=20 \mathrm{mg} / \mathrm{ml}\right)$ was saturated with ammonium nitrate at room temperature. Residual ammonium nitrate was removed by filtration. Ammonia gas (in the form of ammonia vapor from the bottle with a $25 \%$ solution) was bubbled through the yellow filtrate with a syringe until the solution lost its color or crystallization of white needles of the desired $\left[\mathrm{Au}\left(\mathrm{NH}_{3}\right)_{4}\right]\left(\mathrm{NO}_{3}\right)_{3}$ began. After 24 hours of crystallization, the white needles were filtrated and washed with a small amount of cold water, ethanol and

\section{Figure 6}

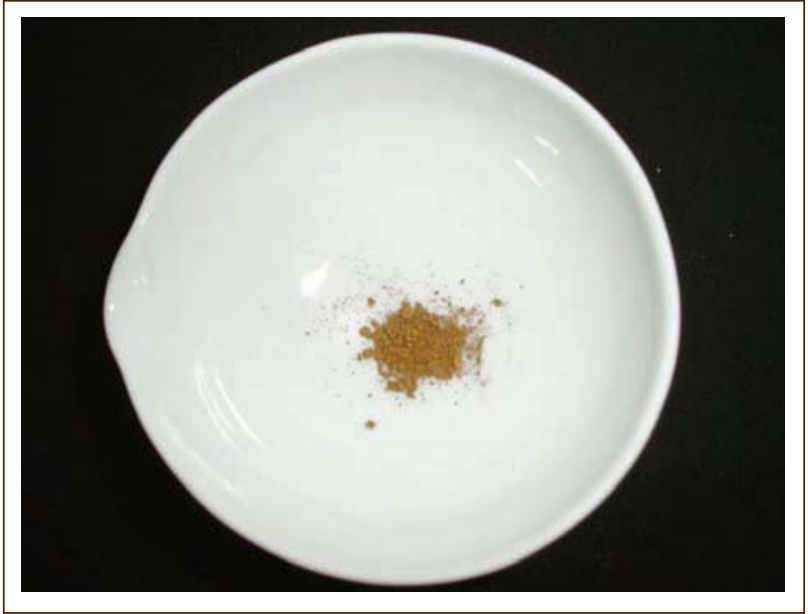

Fulminating gold produced via route a 
Figure 7

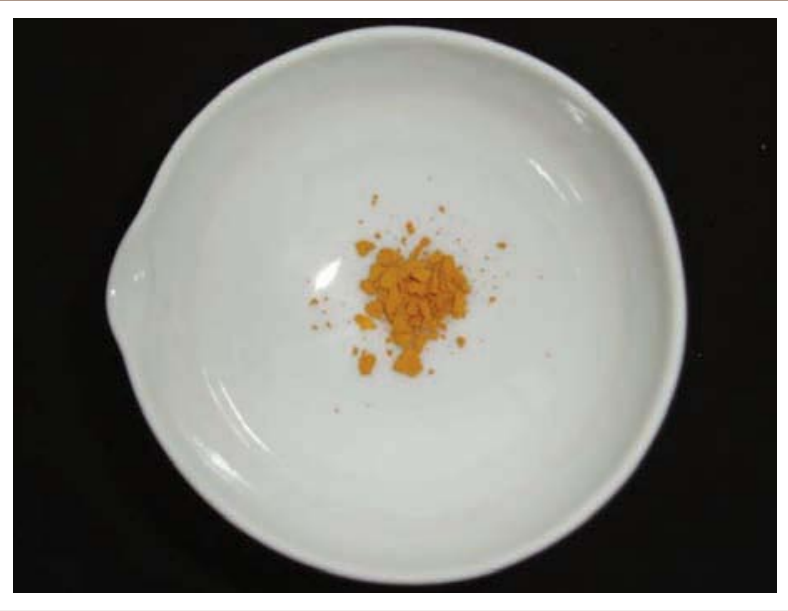

Fulminating gold produced via route $\boldsymbol{b}$

ether. Eventually, a second fraction of $\left[\mathrm{Au}\left(\mathrm{NH}_{3}\right)_{4}\right]\left(\mathrm{NO}_{3}\right)_{3}$ can be obtained from the mother liquor by bubbling ammonia vapor through the solution again. The yield after air drying was approximately $79 \%$. In a second reaction step, the needles were dissolved in water (concentration approximately $23 \mathrm{mg}$ $\left[\mathrm{Au}\left(\mathrm{NH}_{3}\right)_{4}\right]\left(\mathrm{NO}_{3}\right)_{3}$ per $\mathrm{ml} \mathrm{H} \mathrm{H}_{2} \mathrm{O}$ ). Solid ammonium chloride (20fold molar excess compared to the tetraammine complex) was added to the clear solution. After a short time, precipitation of fulminating gold set in. Upon addition of ammonium chloride, the colorless solution first turned yellow on the bottom of the beaker, later orange or light-brown by the formation of finely dispersed fulminating gold (see Fig. 7).

\section{The Hazards of fulminating gold}

It appears that gold scientists are not always aware of the hazards of fulminating gold and the routes of its formation. Occasionally, warnings can be found in literature [33-34], however, reports on the preparation of gold catalysts based on the (potentially hazardous) use of hydrogen tetrachloroaurate(III) and ammonium carbonate or ammonia can be found much more regularly, see e.g. [35-40]. In this chapter, the hazards, safe treatment and disposal of fulminating gold as well as potential alternatives to the use of ammonia are shortly discussed.

\section{Explosive properties}

When initiated, fulminating gold explodes under the formation of a characteristic violet/purple plume of gold aerosols. For initiation, explosives can generally exhibit sensitivity toward impact, friction, electric discharge, thermal shock or high temperatures and other factors like changes in the chemical environment. Standardized tests for the reliable and reproducible determination of the explosive properties (such as the drop hammer or friction sensitivity), however, depend on a defined compound of high purity, because impurities can influence the sensitivity in a wide range. In case of fulminating gold, which is not a homogeneous substance, the declaration of sensitivity data must therefore be regarded as data with "informative character" only. Slight variations in the reaction conditions can influence the properties and lead to more sensitive and thus hazardous products. As stated above, the oxygen content in fulminating gold is proportional, the chloride content reciprocally proportional to the sensitivity. $[18,19]$ Washing the precipitate in boiling water or, even worse, alkaline solutions, increases the sensitivity in a way that the slightest touch with a sheet of paper can initiate the dry substance [41].

For the determination of sensitivity data, we applied standardized drop hammer-, friction- and spark-spraying tests. The drop hammer facility of the LMU has variable drop hammer weights (1,5 and $10 \mathrm{~kg}$ ) and its drop height can be adjusted in any order up to $100 \mathrm{~cm}$. The sample is placed in a steel cylinder. A steel bolt is inserted into the cylinder, which is struck by the falling hammer. The friction tester uses a roughened ceramic plate and a ceramic pistil [42]. The sample is placed on the plate, then the pistil is placed on the sample by means of a lever. The force applied to the sample is varied by standardized weights that can be hung up the lever. For testing, an electric motor moves the plate forward and back. A substance is classified as friction sensitive, if the explosion or decomposition caused by friction is audible. Generally, fulminating gold is much more sensitive toward friction than to impact. This is a less common phenomenon among explosives.

We tested three samples of fulminating gold: Route a fulminating gold (precipitated with 3 and 8 equivalents of ammonia per $\mathrm{Au}^{3+}$ ion, respectively), and route $\mathbf{b}$ fulminating gold. The results of the sensitivity tests are given in Table 4 . Decomposition means a significant change of color without audible or visible explosion.

\section{Table 4}

Sensitivity data of fulminating gold

\begin{tabular}{lllll} 
Sample & Impact (explosion) & Impact (decomposition) & Friction (explosion) & Electric discharge \\
\hline Route $\mathbf{a}\left(\mathrm{NH}_{3}: A u=8: 1\right)$ & $\geq 11.5 \mathrm{~J}^{\mathrm{a}}$ & $\geq 7.5 \mathrm{~J}^{\mathrm{b}}$ & $<5 \mathrm{~N}^{\mathrm{c}}$ & explosion \\
Route $\mathbf{a}\left(\mathrm{NH}_{3}: \mathrm{Au}=3: 1\right)$ & $>100 \mathrm{~J}^{d}$ & $>100 \mathrm{~J}^{d}$ & $<5 \mathrm{Nc}$ & decomposition \\
Route $\mathbf{b}$ & $>100 \mathrm{~J}^{\mathrm{d}}$ & $>100 \mathrm{~J}^{\mathrm{d}}$ & $>360 \mathrm{~N}^{\mathrm{e}}$ & slight decomposition \\
\hline
\end{tabular}

a $5 \mathrm{~kg}$ drop hammer $/ 23 \mathrm{~cm} ;{ }^{b} 5 \mathrm{~kg}$ drop hammer $/ 15 \mathrm{~cm} ;{ }^{c}$ no weight on the lever; ${ }^{d} 10 \mathrm{~kg}$ drop hammer $/ 100 \mathrm{~cm} ;{ }^{e}$ a force of $36 \mathrm{~kg}$ on the sample 


\section{Figure 8}
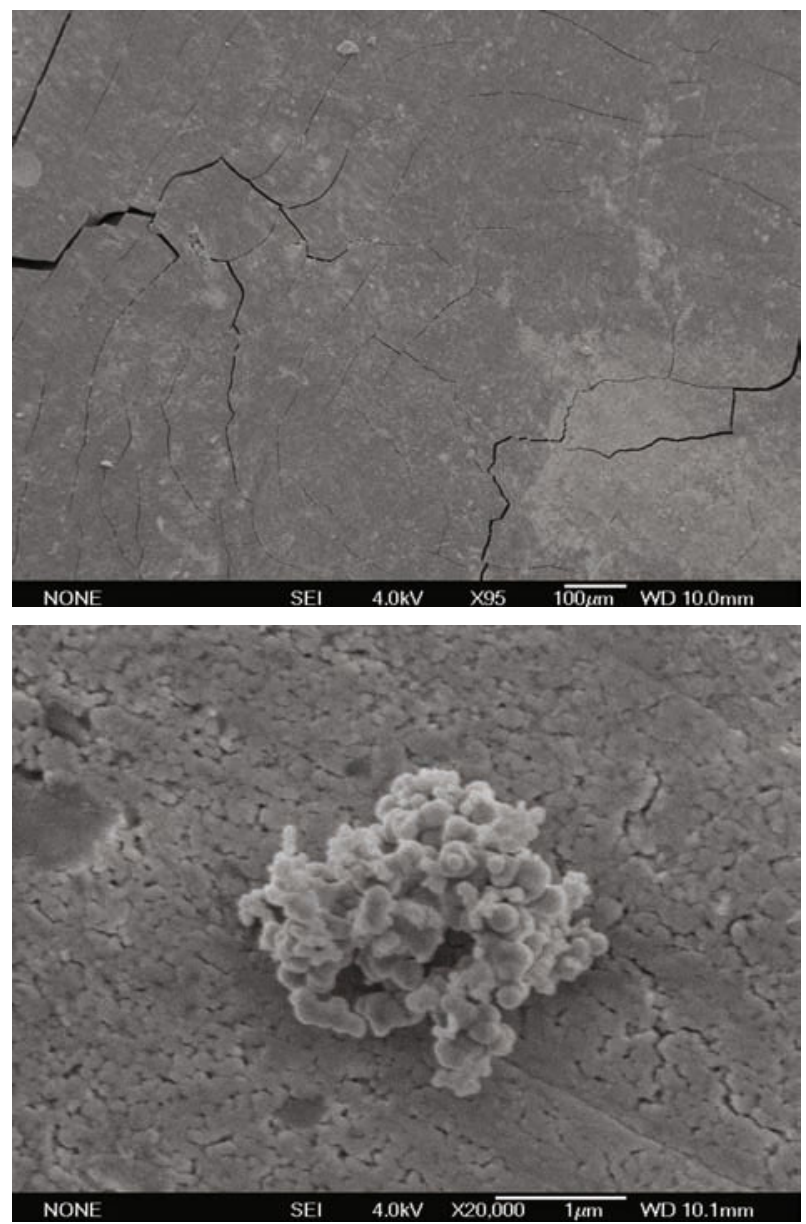

EDX analysis of the plain matrix (mass -\%)

Au 31, N 47, Cl 22, O not detected
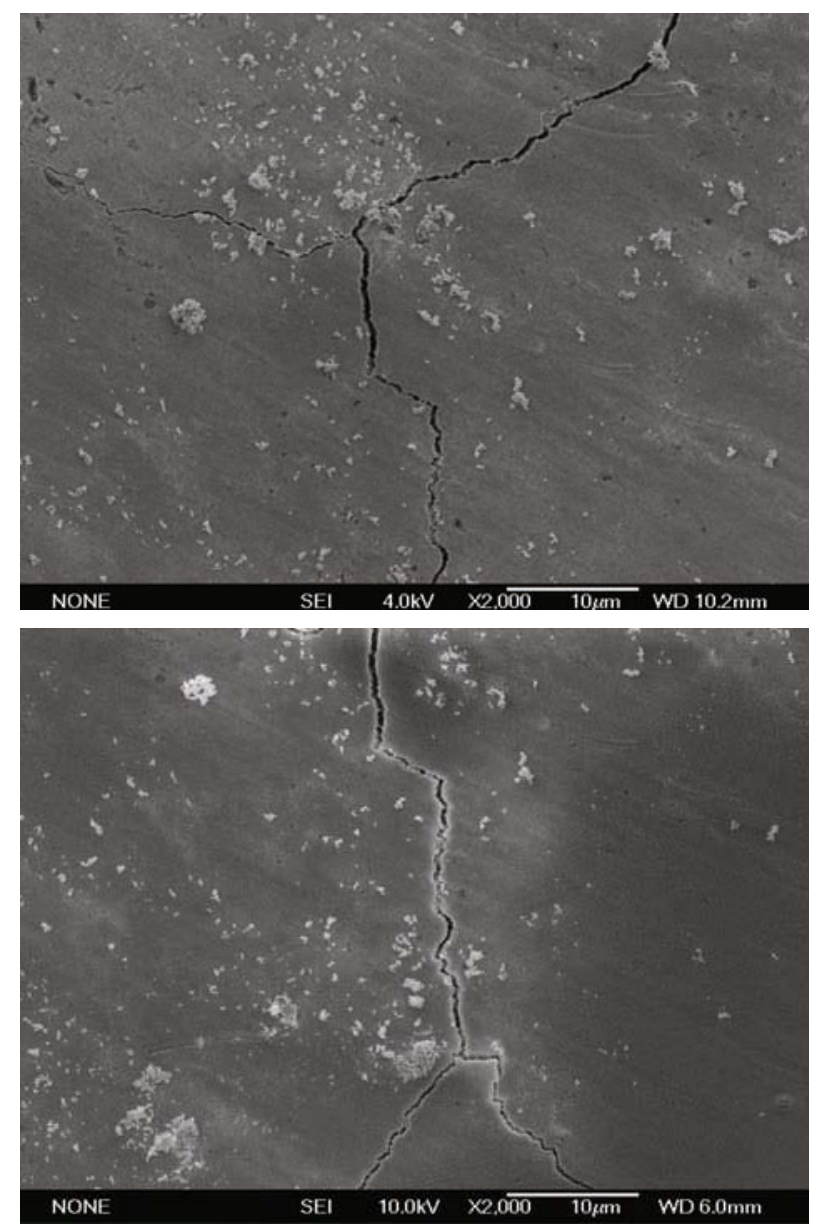

EDX analysis of the fulminating gold globules (mass -\%) Au 40, N 42, Cl 18, O not detected

SEM picture of black, partly decomposed fulminating gold (by the impact of the drop hammer). Globules of undecomposed fulminating gold can be found on the surface

Decomposition of fulminating gold under the impact of the drop hammer yields a thin lustrous black plate. SEM images of this metal-like substance are shown in Figure 8. EDX analytical values confirm that this substance still contains gold, nitrogen and chlorine (qualitative information only).

The upper limit of the thermal stability of fulminating gold varies between 200 and $230^{\circ} \mathrm{C}$. It always explodes or deflagrates in the flame of a Bunsen burner. Fulminating gold exploded violently when struck by a $600 \mathrm{~mW}$ laser beam in the Raman apparatus.

\section{Safety instructions}

CAUTION! Fulminating gold is an energetic material should be synthesized by fully trained personnel and in small amounts only. Proper protective measures should be taken. The following safety instructions provide a summary of all necessary safety precautions to be taken for the safe handling of fulminating gold and, for most readers even more important, instructions how to avoid the formation of this explosive.
The golden rule for your safety:

\section{Avoid any contact of ammonia (either gaseous or in} aqueous solution) to any gold(III) compound.

If, for any reason, this is not possible, follow the safety instructions listed below. Handling of explosives always involves a certain risk. The following rules will reduce the risk to a minimum.

- If possible, use secondary amines or primary amines with a large alkyl group (e.g. mono-t-butyl amine) instead of ammonia to avoid the formation of explosive products.

- Avoid an excess of ammonia (which increases the product's sensitivity) in the course of your reaction. Use as little as possible.

- In your reactions with gold(III) compounds, be aware that some chemicals may release ammonia, e.g. ammonium carbonate or urea at elevated temperature.

- Without a major excess of ammonia, the addition of significant amounts of sodium or potassium cyanide to 
the slightly basics solution can prevent the precipitation of fulminating gold $[35,43]$. Be aware of the formation of very toxic hydrogen cyanide gas from acidic solutions!

- Do not wash the precipitate, neither with water, nor (even worse) with ammonia solutions or bases. Both leads to the formation of even more sensitive and explosive products.

- If you accidentally obtain a precipitate from a reaction of gold(III) compounds and ammonia, do not dry it, but keep it moist. Only the dry product is explosive.

- Precipitation in presence of excess amounts of $\mathrm{NH}_{4}^{+}$and/ or $\mathrm{Cl}^{-}$(e.g. $\mathrm{NH}_{4} \mathrm{Cl}$ or $\mathrm{NH}_{4} \mathrm{NO}_{3}$ ) leads to a less (in case of $\mathrm{Cl}^{-}$) or not explosive (in case of $\mathrm{NH}_{4}^{+}$) product.

- Do not synthesize or handle larger quantities than 500 mg of fulminating gold.

- Use safety equipment when handling fulminating gold, such as: safety goggles, face shield, leather coat, earthening (person and equipment), Kevlar ${ }^{\mathrm{TM}}$ gloves and wrist protectors and ear plugs. In general, avoid the use of glass or metal equipment (e.g. spatula) because of the possible formation of shards or shrapnels in case of an explosion. Use plastic beakers and spatula instead. Only for the drying of wet, freshly precipitated fulminating gold in the desiccator, the use of a glass beaker has turned out as practicable, because fulminating gold tends to adsorb on the bottom of a polypropylene beaker in the course of drying, from where it can be removed only by hazardous scratching.

- Avoid friction to the dry product. Remember its high friction sensitivity. Act in a concentrated way and handle the product with care and precaution.

- For safe disposal of fulminating gold, dissolve it in hydrochloric acid (concentrations > $0.2 \mathrm{M}$ ). Dissolution may consume some time, thus it is advisable to let the suspension stand for at least 24 hours. Thereafter, only a little residue might remain undissolved on the bottom of the beaker. It can be wiped out with a paper towel without a hazard.

\section{Conclusions}

Fulminating gold is a fascinating explosive substance of historic and scientific interest. However, it is a heterogeneous mixture of polymeric compounds with variable properties. Thus its constitution cannot be expressed by a simple formula. Adam's theory that fulminating gold is the product of partial hydrolysis of ${ }_{\infty}^{3}\left[\mathrm{Au}_{2}\left(\mu-\mathrm{NH}_{2}\right)\left(\mu_{3}-\mathrm{NH}\right)_{2}\right] \mathrm{Cl}$ is probably very close to the truth. In magnetic measurements, fulminating gold showed to be diamagnetic. Thus the gold atoms are coordinated by four nitrogen atoms in square planar low-spin complexes. This confirms previous EXAFS analyses. In any case, scientists have to be aware of the hazards involved in the reaction of gold(III) compounds and ammonia. Fulminating gold is unpredictable. Sat dictum.

\section{Acknowledgements}

We would like to thank Prof. Konstantin Karaghiosoff for his numerous and enthusiastic attempts measuring our noncrystalline look-like-crystals on the X-ray diffractometer. We would also like to thank Prof. Joachim Strähle for providing literature and helpful comments to this study and Steffen Schmidt for the SEM investigations. Financial support of this work by the Ludwig-Maximilian University of Munich (LMU), the Fonds der Chemischen Industrie (FCl), the European Research Office (ERO) of the U.S. Army Research Laboratory (ARL) under contract nos. N 62558-05-C-0027 \& 9939-AN01 and the Bundeswehr Research Institute for Materials, Explosives, Fuels and Lubricants (WIWEB) under contract nos. E/E210/4D004/X5143 \& E/E210/7D002/4F088 is gratefully acknowledged. Georg Steinhauser thanks the Austrian Science Fund (FWF) for financial support (Erwin Schrödinger Auslandsstipendium, project no. J2645-N17).

\section{About the authors}

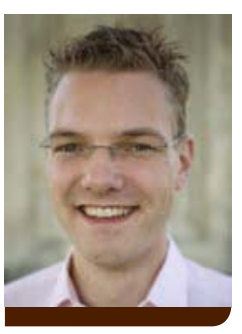

Georg Steinhauser was born in Vienna, Austria, in 1979. He received his diploma in chemistry from the University of Vienna in 2003 and his PhD in radiochemistry from the Vienna University of Technology in 2005. His research interests are in radiochemistry and inorganic chemistry, including industrial and environmental chemistry. He is currently employed at the LMU Munich as an Erwin-Schrödinger-Fellow in the field of energetic materials.

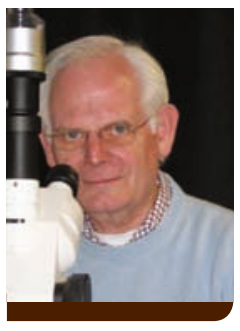

Jürgen Evers was born in Dortmund, Germany, 1941. Until 1965, he worked as laboratory assistent and then studied chemistry at the FU Berlin. He received his Dipl-Chem. (1971) and the Dr. rer. nat. (1974), both from the LMU Munich. Until 1975, he worked at the ETH Zürich in the Solid State Physics Group of G. Busch and E. Kaldis. After the Habilitation (1982) at the LMU Munich, he was Heisenberg-Stipendiat (1984), Priv.-Doz. (1987) and Professor (1992). His research interests are high pressure investigations on Zintl compounds with a belt apparatus (50 kbar) and with a diamond anvil cell (800 kbar). 


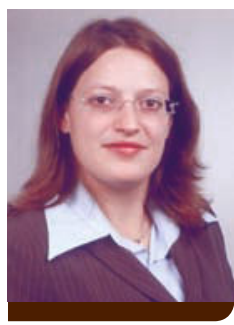

Stefanie Jakob was born in Munich, Germany, in 1979. She received her diploma in chemistry (2004) and her PhD (2007) from the LMU Munich. Her research interests are in inorganic solid state chemistry, especially crystallography and magnetism. She is currently employed at the LMU Munich.

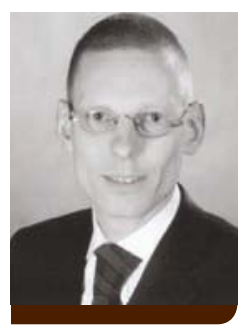

Thomas M. Klapötke was born in Göttingen, Germany, in 1961. He received his Dipl.-Chem. (1984), Dr. rer. nat. (1986), and Habilitation (1990) from the TU Berlin and worked as a PrivatDozent at the same university from 1990 to 1995. After two years (19951997) at Glasgow University, he took up his present position as professor of inorganic chemistry at University of Munich in 1997. His scientific interests include explosives, high-energy-density materials, computational chemistry, azide chemistry, fluorine chemistry, strong oxidizers and nitro chemistry.

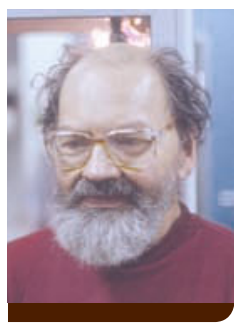

Gilbert Oehlinger was born in Seefeld, Austria, in 1945. He is a laboratory technician. His manifold research interests include $\mathrm{X}$-ray investigations at ambient and at high pressure.

\section{References}

1 S. Schwaertzer, Chrysopoeia Schwaertzeriana - Manuscripta Von der Wahrhafften Bereitung des Philosophischen Steins. Samuel Heil, Hamburg, 1718

2 W. Beck, J. Evers, M. Göbel, G. Oehlinger, T.M. Klapötke, Z. Anorg. Allg. Chem., 2007, 633, 1417

3 O. Croll, Basilica Chymica, G. Tampach, Frankfurt a. Main, 1608, p. 211

4 T. Willis, Diatribe de fermentatione, in: G. Blasius, H. Wetstein (eds.), Opera omnia, Amsterdam, 1682, p. 37

5 P.E. Schoenfelder, US 730800, 1903
6 W.J. Pope, GB 338506, 1929

7 M. Speter, Nitrocellulose, 1930, 1, 128

8 C.W. Scheele, Chemische Abhandlung von der Luft und dem Feuer, Upsala-Leipzig, 1777, p.110

9 Encyclopédie methodique, Chimie, vol. 1, Paris, 1786, p. 639

10 J. Dumas, Ann. Chim. Phys., 1830, 44, 167

11 F. Raschig, Liebigs Ann., 1886, 235, 341

12 T.M. Klapötke, B. Krumm, J.-C. Galvez-Ruiz, Inorg. Chem., 2005, 44, 9625

13 H.-N. Adams, U. Grässle, W. Hiller, J. Strähle, Z. Anorg. Allg. Chem., 1983, 504,7

14 M. Weishaupt, J. Strähle, Z. Naturforsch., 1976, 31b, 554

15 J. Strähle, J. Gelinek, M. Kölmel, Z. Anorg. Allg. Chem., 1979, 456, 241

16 L.H. Skibsted, Acta Chem. Scand., 1979, A33, 113

17 H.-N. Adams, Diploma thesis, Tübingen, 1976

18 H.-N. Adams, PhD thesis, Tübingen, 1985

19 E. Weitz, Justus Liebigs Ann. Chem., 1915, 410, 117

20 U. Gräßle, PhD thesis, Tübingen, 1985

21 J. Psilitelis, PhD thesis, Tübingen, 1999

C.V. Banks, R.V. Vander Haar, R.P. Vander Wal, J. Am. Chem. Soc., 1955, 77,324

\section{4, 512, 16}

Q. Fu, S. Kudriavtseva, H. Saltsburg, M. Flytzani-Stephanopoulos, Chem. Eng. J., 2003, 93, 41 